Ewelina Kina*

\author{
ROZDZIA $七$ VII
}

\title{
Wpływ sieci społecznościowych na wartość kapitału ludzkiego w regionie łódzkim
}

\section{Wstęp}

Proces zdobywania i dyfuzji wiedzy zależy między innymi od poziomu zaufania charakteryzującego daną zbiorowość oraz od zasięgu i wielkości istniejącej sieci kontaktów i współpracy, czyli podstawowych elementów kapitału społecznego. Dodatkowo może być on usprawniony dzięki wykorzystaniu technologii informacyjno-komunikacyjnych. W tym przypadku ICT interpretować można zarówno w wąskim rozumieniu jako narzędzia informatyczne przyspieszające dostęp do informacji i dzielenia się nią oraz w szerszym rozumieniu, jako nowe „metody” komunikacji i współpracy, kształtujące się w wyniku rozwoju między innymi portali społecznościowych. Wiedza stanowi jeden z zasobów decydujących o wartości kapitału ludzkiego. Jej nabywanie oraz dzielenie się nią jest warunkowane jakością środowiska ${ }^{1}$, w którym procesy te zachodză, sposobem jego organizacji, jak również zakresem wykorzystywanych narzędzi komunikacyjnych. Tym samym można wnioskować, że zarówno kapitał społeczny, jak i nowoczesne technologie komunikacyjne (poprzez wpływ na procesy komunikacji i współpracy) determinują wartość kapitału ludzkiego.

\footnotetext{
* Asystent, Katedra Gospodarki Regionalnej i Środowiska, Wydział Ekonomiczno-Socjologiczny, Uniwersytet Łódzki. E-mail: ewelina_kina@uni.lodz.pl

${ }^{1}$ Środowisko w rozumieniu entrepreneurship milieu (środowiska przedsiębiorczości). Szerzej w: A. Jewtuchowicz, Rozwój, środowisko, sieci innowacyjne i lokalne systemy produkcyjne, [w:] K. B. Matusiak, E. Stawasz, A. Jewtuchowicz, Zewnętrzne determinanty rozwoju innowacyjnych firm, Katedra Ekonomii Uniwersytetu Łódzkiego, Łódź 2001, s. 78-82.
} 


\section{Cele i metodyka badań}

Praca koncentruje uwagę na identyfikacji roli narzędzi informacyjnokomunikacyjnych (portali społecznościowych) w kształtowaniu kapitału społecznego, jako jednego z czynników warunkujących efektywność wykorzystania zasobów ludzkich. Głównym celem badania jest zatem ocena wpływu nowoczesnych technologii na wartość kapitału ludzkiego. Ocena ta zostanie dokonana, poprzez identyfikację poziomu wykorzystania narzędzi informacyjno-komunikacyjnych, typu portale społecznościowe, przez organizacje pozarządowe wybranych miast regionu łódzkiego, w zakresie budowania sieci współpracy i powiązań, decydujących o efektywności przepływu wiedzy i informacji. Zasięg przestrzenny badania ograniczono do miast Łódzkiego Obszaru Metropolitalnego, z uwagi na potencjalnie największe możliwe efekty inwestycji w kapitał ludzki, w otoczeniu, które w naturalny sposób koncentruje duże zasoby kapitału ludzkiego i kreatywnego. Przedmiotem badania jest zatem uchwycenie relacji pomiędzy wykorzystaniem narzędzi informacyjno-komunikacyjnych (typu portale społecznościowe), a zdolnością budowania lokalnych sieci powiązań i współpracy, pomiędzy przedstawicielami środowiska pozarządowego, a społecznością.

Uzasadnienie wyboru obszaru badawczego, przedmiotu oraz podmiotów badania z jednej strony wynika $z$ klasycznych teorii kapitału społecznego, z drugiej zaś ze współczesnych trendów w zakresie procesów komunikacji². Już R. Putnam w swym dziele pt.: „Demokracja $w$ działaniu” stawia hipotezę, że efektywne rządy są możliwe jedynie wtedy, gdy zarówno osoby sprawujące władzę, jak i te poddające się jej, mają wspólną cechę: silną skłonność do kooperacji. Tym samym w efektywnej demokracji muszą istnieć mechanizmy, które pobudzają jednostki do zachowań kooperacyjnych. Zdaniem Putnama, te mechanizmy powstają głównie za sprawą stowarzyszeń, dzięki którym ludzie zrzeszają się i współpracują dla osiagnnięcia wspólnego celu. Takie mniej lub bardziej regularne kontakty prowadzą do wzrostu wzajemnego zaufania, które z czasem zaczyna wykraczać poza ramy stowarzyszenia i przenosi się na inne sfery życia społecznego. Jego zdaniem, ośrodkiem rozprzestrzeniania się zaufania, norm wzajemności i gotowości do kooperacji są właśnie stowarzyszenia. Dodatkowo autor ten dodaje, że to właśnie sieci obywatelskiego zaangażowania stanowią zasadniczą formę społecznego kapitału, a większe zagęszczenie tych sieci w społeczeństwie daje większe prawdopodobieństwo, że jednostki będą skłonne współpracować dla wspólnych korzyści ${ }^{3}$.

${ }^{2}$ Szerzej: E. Kina, Rola technologii informacyjno-komunikacyjnych $i$ sieci spolecznych w kształtowaniu kapitału ludzkiego, artykuł powyżej.

${ }^{3}$ R. D. Putnam, Demokracja w działaniu. Tradycje obywatelskie we wspótczesnych Włoszech, Kraków 1995, s. 269. 
Istotność szeroko rozumianych organizacji pozarządowych, dla tworzenia kapitału społecznego, zauważają również autorzy Diagnozy społecznej 2007 stwierdzając, że: ,przestrzenią, w której i poprzez którą głównie tworzony jest kapitał społeczny, jest trzeci sektor ${ }^{4}$ (dobrowolne organizacje pozarządowe i pozarodzinne - stowarzyszenia i fundacje) - sieć formalnych związków. Sieć nieformalnych związków (rodzinnych, towarzyskich) także może tworzyć kapitał społeczny. Efektywność kapitału społecznego bywa mniejsza w przypadku związków nieformalnych, ponieważ w tym przypadku większe jest ryzyko maksymalizowania korzyści partykularnych kosztem dobra wspólnego",5. Dodatkowa wartość aktywności jednostek (rozumiana tutaj głównie jako działalność w trzecim sektorze), dla tworzenia kapitału społecznego, wynika z faktu, że jest ona przejawem również innych aspektów tego pojęcia. Bez stosunkowo wysokiego poziomu zaufania, poczucia podmiotowości czy gotowości do działania na rzecz innych i wspólnego celu, aktywność ta nie jest możliwa ${ }^{6}$. Argumenty te mogą potwierdzać trafność wyboru organizacji pozarządowych jako podmiotu badań.

Odnosząc się natomiast do współczesnych procesów komunikacji, wiele możliwości angażowania się społeczeństwa stwarza Internet. Ciekawe wyniki w tym obszarze prezentuje badanie: Zaangażowanie Społeczne Polaków, przeprowadzone przez TNS Polska na zlecenie Groupon Polska ${ }^{7}$. Respondenci zapytani o to, czy Internet ułatwia angażowanie się w sprawy społeczne, w zdecydo-

\footnotetext{
${ }^{4}$ Trzeci sektor to określenie stosowane wobec ogółu organizacji pozarządowych. Nazwa ta nawiązuje

do koncepcji układu, dzielącego aktywność społeczno-gospodarczą nowoczesnych państw demokratycznych

na trzy sektory. Sektor pierwszy to instytucje państwowe (administracja publiczna, sektor państwowy), sektor drugi - podmioty for-profit, nastawione na zysk (sektor prywatny) oraz sektor trzeci czyli organizacje, które ani nie są nastawione na zysk (non-profit), ani nie stanowią elementu struktury państwa. Stanowi on specyficzny, usytuowany między rynkiem a państwem, obszar w gospodarce, który zawiera w sobie wszystkie możliwe metody realizacji zadań społecznych, które nie są w sposób bezpośredni wykonywane przez sektor prywatny i publiczny. Organizacje trzeciego sektora powoływane są do życia by zaspokoić potrzeby, które nie mogą zostać zapewnione ani przez państwo ani przez rynek. (Szerzej: K. Kietlińska, Rola trzeciego sektora w spoteczeństwie obywatelskim, Wydawnictwo Difin, Warszawa 2010, s. 71-74). Wobec podmiotów tworzących III sektor, w ostatnim czasie najczęściej - przynajmniej w dokumentach administracji państwowej - używa się pojęcia „organizacje pozarządowe”. Definicja organizacji pozarządowych została zawarta w Ustawie z dnia 24 kwietnia 2003 r. o działalności pożytku publicznego i o wolontariacie, Dz. U. 2003 Nr 96, poz. 873, Art. 3.

${ }^{5}$ J. Czapiński, T. Panek (red.), Diagnoza społeczna 2007. Warunki i jakość życia Polaków. Raport, Warszawa 2007, s. 264.

${ }^{6}$ D. Moroń, Aktywność w trzecim sektorze jako jeden z wymiarów kapitalu społecznego [w:] Kapitat ludzki i spoteczny. Wybrane problemy teorii i praktyki, D. Moroń (red.), Wydawnictwo Uniwersytetu Wrocławskiego, Wrocław 2009, s. 120.

${ }^{7}$ Badanie zostało przeprowadzone w dniach 31.05-05.06.2013 roku metodą CAWI na reprezentatywnej grupie 500 użytkowników Internetu w wieku 18-60 lat.
} 
wanej większości nie mieli co do tego wątpliwości. Ponad 92\% badanych odpowiedziało twierdząco, a ponad połowa (57\%) była w swej opinii zdecydowana. Jedynie $2 \%$ internautów zanegowało rolę Internetu w tym zakresie. Zatem ogólne przekonanie, że Internet ułatwia angażowanie się w sprawy społeczne jest powszechne i, jak pokazuje badanie, niezależne od płci, wieku czy miejsca zamieszkania. Analizując poszczególne rodzaje aktywności okazuje się, że najpopularniejsze wśród badanych internautów jest ocenianie produktów i usług (równo połowa osób deklarowała taką aktywność). Kolejne formy angażowania dotyczyły udziału w dyskusjach na forach, blogach i serwisach społecznościowych oraz udostępniania znajomym informacji o akcjach społecznych $(38 \%$ ankietowanych). Więcej niż co trzeci respondent podpisał w Internecie petycje (35\%). Jedynie $16 \%$ internautów zadeklarowało, że nie wykonało żadnych z wymienionych w pytaniu czynności, co jednocześnie oznacza, że zdecydowana większość (ponad $80 \%$ ) podejmuje aktywności społeczne w Internecie. Autorzy badania zwrócili również uwagę na pewne widoczne zależności. Pierwsza dotyczyła związku pomiędzy poziomem wykształcenia, a stopniem aktywności $\mathrm{w}$ Internecie. Zdecydowanie mniej zachowań biernych prezentowali respondenci z wyższym wykształceniem. Kobiety w porównaniu do mężczyzn częściej udostępniają znajomym informacje o akcjach lub inicjatywach społecznych $(43 \%$ w porównaniu do $34 \%$ ), ale za to rzadziej dyskutują na forach, blogach czy portalach społecznościowych (32\% wobec $44 \%)$. Częstszą aktywność w postaci korzystania z narzędzi dostępnych przez portale społecznościowe wykazują ludzie młodsi, w wieku 18-29 lat. Prawie połowa $\mathrm{z}$ nich (46\%) udostępnia informacje o akcjach społecznych i ,lubi” inicjatywy na ich profilach $(47 \%)^{8}$. Potwierdza to przypuszczenie, że obecnie to właśnie różnego rodzaju portale społecznościowe stają się nową platformą aktywności obywateli, wymiany informacji, wiedzy, doświadczeń, budowania sieci kontaktów.

Uwzględniając wyżej przedstawione tendencje, podmiotem badania stały się organizacje pozarządowe wybranych miast Łódzkiego Obszaru Metropolitalnego. Badanie składało się z dwóch części. Pierwsza część miała na celu ogólną ocenę skali wykorzystania (popularności) portali społecznych, jako miejsca wymiany informacji i wiedzy wśród organizacji pozarządowych. Dodatkowo na podstawie wyników tej cześci badania został dokonany wybór jednostek, zakwalifikowanych do dalszych badań terenowych. Pierwsza część badania została zrealizowana w lipcu $2012 \mathrm{r}$. W pierwszym etapie zostały poddane analizie organizacje pozarządowe ${ }^{9}$ wszystkich miast podregionu łódzkiego, z wyłączeniem Łodzi, jako głównego ośrodka metropolitalnego, w znacznym stopniu odbiega-

${ }^{8}$ J. Skrzyńska, Badanie: Zaangażowanie Społeczne Polaków, Zespół Badań Społecznych OBOP w TNS Polska, s. 16-17.

${ }^{9}$ Lista organizacji pozarządowych została sporządzona na podstawie baz NGO dostępnych na oficjalnym portalu organizacji pozarządowych www.ngo.pl (Dostęp: lipiec 2012 r.). 
jącego zarówno pod względem liczby mieszkańców, jak i stopnia rozwoju trzeciego sektora od pozostałych. Wykorzystując dwie techniki badań: desk research oraz obserwację quasi uczestniczącą - autor, stając się członkiem jednego z portali społecznościowych - serwisu Facebook, weryfikował, czy dana organizacja posiada na nim swoje konto (własny profil). Rodzaj obserwowanego portalu był również doborem celowym. Wynikał on z faktu, że Facebook stanowi obecnie największą globalną sieć społecznościową zarówno pod względem liczebności użytkowników, jak i czasu, jaki spędzają oni na stronie. Jego użytkownicy pochodzą z wszelkich grup wiekowych i demograficznych. Dodatkowo specyfika tego serwisu polega na tym, że został on wyposażony w szereg funkcji, których nie posiadają inne portale tego typu, a które pomogły stworzyć bezpieczne, przyjazne i zaangażowane środowisko $\mathrm{z}$ wartościowymi informacjami, którymi użytkownicy są skłonni się dzielić (np. uwierzytelnianie według domeny adresu mailowego, ustawienia prywatności, funkcję newsfeed umożliwiającą śledzenie aktualnych aktywności znajomych) ${ }^{10}$. Według raportu „Europe Digital Future in Focus 2013" wśród Europejczyków Facebook.com jest drugą (po Google.com) najpopularniejszą witryną internetową na Starym Kontynencie. Korzystanie z platform społecznościowych to trzecia (po sprawdzaniu poczty elektronicznej oraz prognozy pogody), najpopularniejsza aktywność wśród użytkowników smartfonów w Europie. Ponad 70\% z nich deklaruje, że odwiedza Facebooka, Twittera czy blogi. Popularność Facebooka widoczna jest również w rankingu stron pod względem liczby wyszukujących. Tutaj Facebook znów znajduje się na drugiej pozycji, zaraz po Google.com ${ }^{11}$. Spośród 288 organizacji pozarządowych uwzględnionych $\mathrm{w}$ analizowanych bazach, które funkcjonowały w 9 miastach poniżej 50 tys. mieszkańców (Ozorków, Głowno, Aleksandrów Łódzki, Stryków, Brzeziny, Konstantynów Łódzki, Koluszki, Rzgów, Tuszyn) jedynie wśród 29 udało się zidentyfikować posiadanie konta na Facebooku. Na terenie 2 pozostałych z wybranych do badania miast Łódzkiego Obszaru Metropolitalnego (Zgierza i Pabianic) łącznie funkcjonowało 276 organizacji pozarządowych, a 59 z nich było zarejestrowanych na portalu Facebook. $\mathrm{Na}$ tym etapie badania możliwe jest jedynie bardzo ogólne wnioskowanie, jednak widać, że stopień popularności, wykorzystania portali społecznościowych, mierzony liczbą organizacji posiadających konto na Facebooku, można wstępnie ocenić jako niski. Szczególnie widoczne było to w mniejszych miastach, gdzie ok. jedynie $10 \%$ badanych organizacji założyło na portalu własny profil. Ze względu na specyfikę poszukiwanych informacji oraz chęć uzyskania danych w dużej części o charakterze jakościowym, wyznaczono dodatkowe kryteria

${ }^{10}$ C. Shih, Era Facebooka. Wykorzystaj sieci spolecznościowe do promocji, sprzedaży i komunikacji z Twoim klientem, Wydanie II, Wydawnictwo HELION, Gliwice 2012, s. 39-42.

${ }_{11}$ Europe Digital Future in Focus 2013, comScore, http://www.comscore.com/Insights/ Blog/2013_Digital_Future_in_Focus_Series 
doboru jednostek do dalszej analizy. Dotyczyły one rodzaju organizacji pozarządowej oraz ostatniej aktywności na portalu społecznościowym. Do badania zostały wybrane organizacje pozarządowe, które zgodnie ze swym statutem realizują cele $\mathrm{z}$ różnych obszarów (nie ograniczają się do zadań związanych z jednym rodzajem aktywności) i są istotne z punktu widzenia rozwoju społeczno-gospodarczego danej jednostki oraz nie stanowią filii organizacji posiadającej swą główną siedzibę w innym mieście. $Z$ badania zostały zatem wyłączone kluby sportowe, zamiejscowe filie organizacji oraz Ochotnicze Straże Pożarne. Kryterium ostatniej aktywności organizacji na portalu społecznościowym oznaczało, że dany podmiot zostanie zakwalifikowany do badania, jeśli w ciągu ostatnich 6 miesięcy wykazywał jakąkolwiek aktywność na portalu (zamieszczał posty, zdjęcia, komentarze, informacje o wydarzeniach, polubienia stron itp.).

Ostatecznie do drugiej części badań zostało zakwalifikowanych 11 organizacji pozarządowych z 7 analizowanych miast (Zgierza, Pabianic, Koluszek, Głowna, Konstantynowa Łódzkiego, Brzezin i Aleksandrowa Łódzkiego). $\mathrm{W}$ drugiej części wykorzystano reaktywne metody badawcze, w postaci osobistego wywiadu kwestionariuszowego, uzupełnionego wywiadami telefonicznymi. Wywiady te zostały przeprowadzone z przedstawicielami, wydelegowanymi przez dane organizacje, $\mathrm{w}$ terminie od września do listopada 2012 roku. Na tym etapie miał zostać przede wszystkim zrealizowany cel, dotyczący oceny roli i miejsca narzędzi informacyjno-komunikacyjnych (typu portale społecznościowe), w przepływie informacji, transferze wiedzy, budowaniu relacji i powiązań. Jego realizacja w praktyce sprowadzała się do odpowiedzi na bardziej szczególowe problemy badawcze:

1. Czy organizacje pozarządowe wykorzystują portale społecznościowe do komunikacji z innymi organizacjami społecznymi i obywatelami, aktywizując ich do wymiany informacji i wiedzy?

2. Czy narzędzia informacyjno-komunikacyjne ułatwiają/usprawniają komunikację oraz wymianę wiedzy? Jeśli tak, to jakiej i w jakim zakresie?

3. Jaki jest zasięg przestrzenny wymiany informacji i sieci współpracy, powstałych w wyniku wykorzystania narzędzi ICT typu portale społecznościowe?

4. Czy i w jakiej formie współpraca zapoczątkowana w świecie wirtualnym przenosi się i ma konsekwencje w świecie realnym?

Tak postawione pytania pozwolą zweryfikować hipotezę, że rozwój narzędzi informacyjno-komunikacyjnych determinuje rozwój kontaktów i powstawanie sieci współpracy o charakterze lokalnym, ułatwiając tym samym przepływ informacji i dyfuzję wiedzy. Inaczej rzecz ujmując rozwój narzędzi ICT determinuje rozwój kapitału społecznego, decydującego o wartości kapitału ludzkiego i umożliwiającego jego lepsze wykorzystanie. 


\section{Wykorzystanie portali społecznościowych przez organiza- cje pozarządowe w zakresie wzmacniania wartości kapita- łów ludzkiego i społecznego}

Zagadnienia związane z identyfikacją skali i zakresu wykorzystania portali społecznościowych, w celu wzmacniania oraz efektywniejszego wykorzystania zasobów ludzkich, są złożone i wymagają zwrócenia uwagi na wiele aspektów. Nie ma wątpliwości, że warunkiem koniecznym osiagania korzyści w tym obszarze jest faktyczne zaangażowanie i aktywność na portalu, poparta chęcią i skłonnością do dzielenia się informacjami, wymiany wiedzy i doświadczeń. Aby zatem zweryfikować, na ile i w jakich obszarach portale społecznościowe przyczyniają się do rozwoju kapitału ludzkiego, poprzez usprawnianie procesów komunikacji i budowanie współpracy, należy w pierwszej kolejności zweryfikować rodzaj, częstotliwość i zakres faktycznej aktywności organizacji pozarządowych na serwisach internetowych. Kolejnym krokiem jest ocena, na ile serwisy te modyfikuja procesy komunikacji oraz współpracy w badanych podmiotach (również w kontekście zasięgu przestrzennego), stając się tym samym podstawą do budowania i rozwoju kapitału społecznego. Ostatni element analizy będzie się koncentrował na sprawdzeniu, w jakim zakresie nowe możliwości komunikacji i współpracy rzeczywiście wpływają na transfer wiedzy.

6 spośród 11 analizowanych organizacji pozarządowych jest organizacjami młodymi (które rozpoczęły swoją działalność w ciąu ostatnich 2 lat). Średnio podmioty te posiadają od ok. 8 do 50 członków ${ }^{12}$. Wśród tematów swojej działalności wskazują: edukację kulturalną, promocję kultury, ochronę i upowszechnianie dziedzictwa kulturowego oraz przyrodniczego, przeciwdziałanie dyskryminacji i wyrównywanie szans wśród dzieci i młodzieży, przeciwdziałanie uzależnieniom i patologiom społecznym, promowanie zdrowego stylu życia. Wśród partnerów prowadzonej działalności najczęściej wskazywane są władze lokalne (urzędy miast) oraz inne organizacje pozarządowe (w obu przypadkach takie partnerstwo deklarowały 4 organizacje). Współpraca z lokalnymi podmiotami prywatnymi była popularna jedynie wśród 2 organizacji. Respondenci wskazywali dodatkowo na takich partnerów prowadzonej działalności jak: Miejski Ośrodek Kultury, Radę Organizacji Pozarządowych, Miejski Zakład Komunalny, patronów medialnych (lokalną telewizję i radio), Młodzieżowy Dom Kultury, Polską Akademię Nauk, Park Kulturowy Miasto Tkaczy w Zgierzu, Muzeum Narodowe w Warszawie.

Analizowane organizacje pozarządowe wykorzystują narzędzia informacyjno-komunikacyjne o charakterze najbardziej interaktywnym. Gdy respondenci zostali zapytani, czy korzystają z takich ogólnodostępnych narzędzi komunika-

\footnotetext{
${ }^{12}$ Jedynie w przypadku 1 organizacji liczba ta przekraczała 50 osób.
} 
cyjnych jak: czaty, blogi, fora/grupy dyskusyjne itp., 6 spośród nich zadeklarowało aktywność na forach i grupach dyskusyjnych, 3 organizacje korzystają z możliwości, jakie dają blogi i 2 wykorzystują do komunikacji czaty. Zwracając uwagę na specyfikę poszczególnych wybranych przez respondentów narzędzi należy podkreślić, że fora dyskusyjne są tą formą, która w największym stopniu umożliwia wymianę wiedzy i doświadczeń. Służą bowiem do dzielenia się informacjami i poglądami między osobami o podobnych zainteresowaniach, czy wręcz wśród grup ekspertów. Często dotyczą konkretnych wątków i skupiają się wokół określonego problemu. Blogi stanowią swojego rodzaju pamiętniki, czy też dzienniki porządkujące wydarzenia w sposób chronologiczny, gdzie możliwe jest $\mathrm{w}$ zasadzie jedynie ich komentowanie. Czaty z kolei najczęściej sprowadzają się do tzw. internetowych, z reguły wielowątkowych, pogawędek. W tym układzie, forum dyskusyjne wydaje się być narzędziem najbardziej zaawansowanym, z punktu widzenia wymiany wiedzy specjalistycznej.

Przechodząc do zasadniczego przedmiotu pierwszego elementu badań, czyli aktywności organizacji pozarządowych na serwisach społecznościowych, należy stwierdzić, że w zdecydowanej większości ogranicza się ona do aktywności na jednym portalu - Facebook.com. Jedynie 2 spośród badanych podmiotów zadeklarowały korzystanie, z coraz mniej już popularnego serwisu nasza-klasa.pl i tylko 1 podmiot jest aktywny na portalu Twitter. Większość organizacji działa na portalu społecznościowym od ok. roku. $Z$ jednej strony fakt ten mógłby świadczyć o dość późnym i stosunkowo niewielkim zainteresowaniu tego rodzaju aktywnością, jednak uwzględniając to, że przeważająca część organizacji to podmioty młode, wniosek ten może być zbyt pochopny.

Kolejnym wskaźnikiem wybranym do analizy aktywności organizacji na portalach społecznościowych była częstotliwość ich wykorzystania.

Wykres 1. Częstotliwość korzystania z portali społecznościowych przez organizacje pozarządowe (w \%)

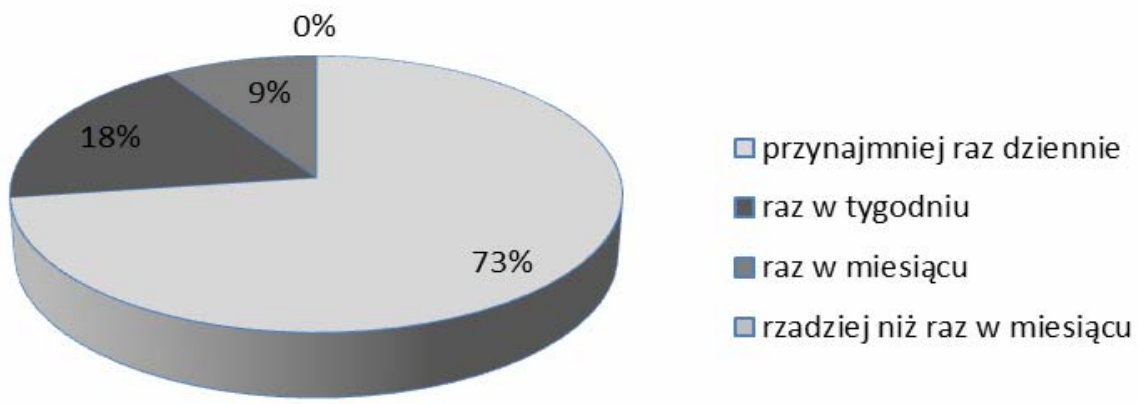

Źródło: Opracowania własne na podstawie danych zgromadzonych podczas badania 
$73 \%$ spośród badanych organizacji zadeklarowało, że korzysta z portali społecznościowych przynajmniej raz dziennie, $18 \%$ pojawia się na portalu raz w tygodniu, 9\% raz w miesiącu. Żaden z badanych podmiotów nie jest aktywny na serwisie rzadziej niż raz w miesiącu. Informacja ta, znając specyfikę funkcjonowania portali społecznościowych, jest bardzo istotna z punktu widzenia możliwości budowania sieci współpracy. Tylko poprzez aktywne działanie na takim serwisie, śledzenie na bieżąco zdarzeń, które są na nim prezentowane istnieje możliwość czerpania z nich korzyści dla własnej działalności.

Wykres 2. Liczba znajomych („fanów”) organizacji pozarządowych na stronach Facebooka (w szt.)

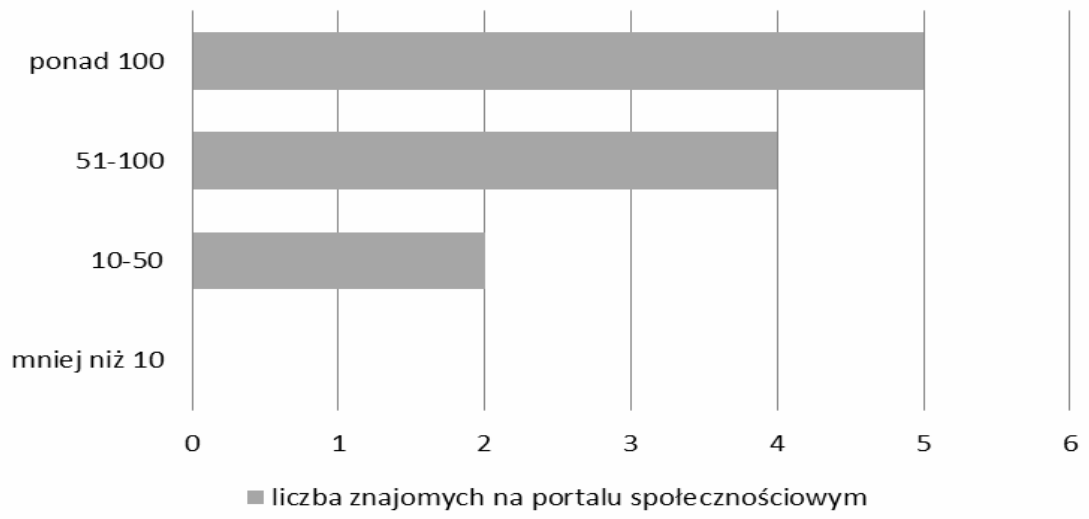

Źródło: Opracowania własne na podstawie danych zgromadzonych podczas badania

Analogiczna sytuacja dotyczy liczby znajomych, jaką posiada dana organizacja na swojej stronie na portalu społecznościowym (wykres 2.). Im szersza, bardziej rozległa sieć kontaktów (mierzona właśnie między innymi liczbą „fanów" danej organizacji), tym większe możliwości szybszego dotarcia do informacji oraz z informacją. Ta wielość kanałów dojścia do wiadomości i jednocześnie jej odbioru, może okazać się kluczowym elementem sukcesu danej organizacji. W przypadku analizowanych podmiotów żaden nie posiadał mniej niż 10 znajomych. Najwięcej, 5 spośród nich deklarowało, że ich sieć znajomych liczy ponad 100 osób. Niewiele mniej, bo 4 organizacje wskazały, że liczba ich znajomych na portalu wynosi między 50 a 100 osób. Od 10 do 50 znajomych miały jedynie 2 organizacje. Biorąc pod uwagę, że w większości są to organizacje z małych miast i dodatkowo praktycznie wszystkie funkcjonują na portalu społecznościowym, od ok. roku liczba 100 znajomych „fanów” to dość dużo. Ciekawie wypada również porównanie liczby posiadanych znajomych z częstotli- 
wością korzystania z portalu społecznościowego. Wynika z niego, że największą częstotliwością odwiedzania swojego profilu cechują się organizacje, które posiadają na nich najwięcej znajomych. Taka zależność może świadczyć o tym, że wraz ze wzrostem, rozwojem sieci kontaktów rosną zdaniem organizacji potencjalne i oczekiwane korzyści z aktywności na portalu. Występują większe możliwości w zakresie znalezienia interesujących i istotnych informacji.

Podsumowując aktywność organizacji pozarządowych, w zakresie wykorzystania narzędzi informacyjno-komunikacyjnych (głównie typu portale społecznościowe) widać , że niestety jest ona dość ograniczona. Odnosi się bowiem w przeważającej większości do wykorzystania jednego konkretnego narzędzia portalu Facebook. Im bardziej rozbudowane sieci kontaktów posiadają organizacje, tym są skłonniejsze do większej aktywności na portalu. Tworzy to możliwość powstania samonapędzającej się platformy, częstej wymiany wiedzy i doświadczeń pomiędzy rosnącym gronem osób.

Drugi element tej części analizy będzie skoncentrowany na ocenie wpływu portali społecznościowych na procesy komunikacji i współpracy. Zanim jednak zostaną poddane ocenie cele i efekty aktywności organizacji pozarządowych na serwisach społecznościowych, warto zwrócić uwagę na motywy, dla których podmioty zdecydowały się na wykorzystanie tych narzędzi w swojej działalności (na podstawie jakich postaw, przekonań i oczekiwań organizacje postanowiły aktywnie włączyć się do grona społeczności facebookowej).

Wykres 3. Przyczyny i motywy wykorzystania (dołączenia do) portali społecznościowych przez organizacje pozarządowe

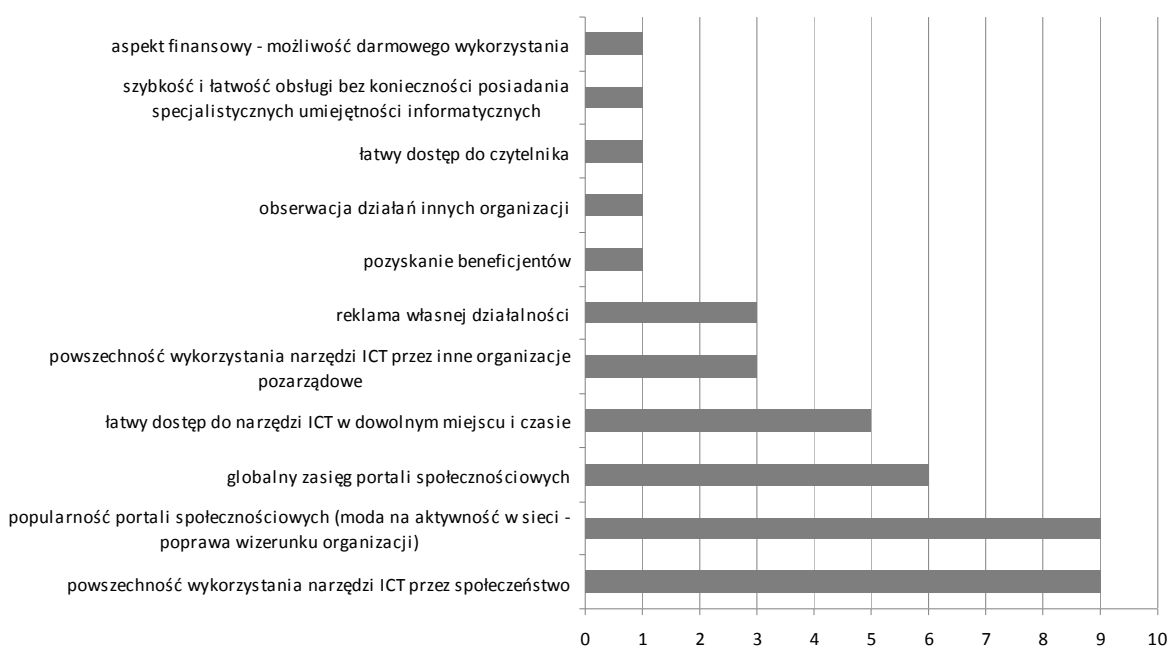

Źródło: Opracowania własne na podstawie danych zgromadzonych podczas badania 
Organizacje, przedstawiając motywy i przekonania, jakie wpłynęły na ich decyzję o przyłączeniu się do portalu, mogły dokonać więcej niż jednego wskazania. Najistotniejsze z ich punktu widzenia okazały się dwie kwestie. Pierwsza to powszechność wykorzystania narzędzi tego typu przez społeczeństwo. Druga wiąże się z popularnością portali społecznościowych, wynikającą $\mathrm{z}$ mody na aktywność w sieci, za pomocą której możliwe jest kreowanie wizerunku nowoczesnej organizacji. Kolejnym wskazaniem, którego dokonała ponad połowa respondentów, był globalny zasięg portali społecznościowych. 5 organizacji jako istotne uznało łatwy dostęp do narzędzi informacyjno-komunikacyjnych w dowolnym miejscu i czasie. 3 organizacje zwróciły uwagę na potencjalną możliwość reklamy własnej działalności, dzięki aktywności na portalu oraz na przekonanie o powszechności wykorzystania tych narzędzi przez inne organizacje pozarządowe. Pozostałe motywy otrzymały po jednym wskazaniu. Warto jednak zwrócić wśród wskazań uwagę na dwa, które zostały dodatkowo zaproponowane przez respondentów w kategorii „inne”. Chodzi mianowicie o aspekt finansowy, czyli możliwość bezpłatnego wykorzystania portalu dla własnych korzyści, czy to związanych z promocją organizacji, pozyskaniem informacji, czy zdobyciem cennych kontaktów. Kolejne, to łatwość i szybkość obsługi tego narzędzia, niewymagająca specjalistycznych umiejętności informatycznych. Każdy może administrować profilem na portalu społecznościowym, co zdaniem organizacji eliminuje konieczność prowadzenia strony internetowej, często wymagającej profesjonalnej obsługi. Najpopularniejsze motywy wykorzystania portali społecznościowych wskazywane przez organizacje mogą świadczyć o tym, że stając się członkiem serwisu, liczyły one na dostęp do szerokiego grona odbiorców prezentowanych przez nich treści. W mniejszym stopniu miały zamiar obserwacji działań innych organizacji, zależało im bardziej na łatwości dostępu do narzędzi ICT i ich popularności wśród społeczności.

Respondenci zapytani o aktualne cele, jakie przyświecają im podczas bieżącego udzielania się i korzystania z portalu społecznościowego, wskazywali głównie na autoprezentację (wykres 4). Bieżąca analiza profili badanych organizacji w przeważającej cześci potwierdza ich aktywność w deklarowanym obszarze. 8 spośród wybranych organizacji systematycznie dzieli się informacjami na temat wydarzeń, które organizuje, bądź w których weźmie udział, planowanych i już zorganizowanych spotkań, projektów, konkursów, wyjazdów, itp. Analiza pozostałych celów działania i rozkładu ich popularności wśród badanych organizacji pokazuje, że są one dość zbieżne i nie odbiegają w znaczący sposób od oczekiwań sprzed przystąienia do portalu. Na nieco wyższą pozycję wysunęła się chęć promocji własnej działalności. Spośród wszystkich respondentów aż 9 wskazało na ten cel, podczas gdy jedynie 3 organizacje wskazały ją jako motywy włączenia się w społeczność portalu. 
Wpływ sieci społecznościowych na wartość kapitału ludzkiego...

Wykres 4. Cele, dla których organizacja udziela się na portalu społecznościowym

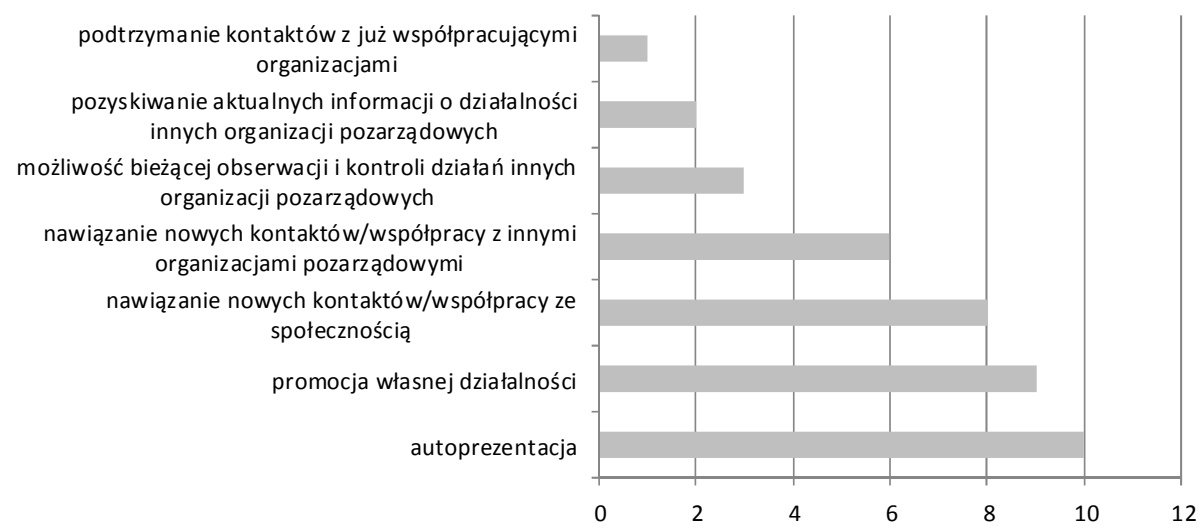

Źródło: Opracowania własne na podstawie danych zgromadzonych podczas badania

Wciąż przeważająca część podmiotów liczy na nawiązanie nowych kontaktów, bądź współpracę ze społecznością oraz innymi organizacjami pozarządowymi. Na dalszych pozycjach znalazła się chęć kontroli, obserwacji i pozyskiwania aktualnych informacji o działalności innych organizacji. Ciekawym zjawiskiem jest fakt, że tylko jeden podmiot, jako cel wskazał chęć podtrzymania kontaktów z już współpracującymi organizacjami. Wynikać z tego może, że instytucje te nie postrzegają portali społecznościowych, jako platform do kontynuowania wcześniej wypracowanych relacji.

Znając główne cele udzielania się w serwisie społecznościowym, wśród których na wysokiej (choć nie priorytetowej) pozycji plasuje się skłonność do nawiązywania kontaktów i współpracy z obywatelami oraz innymi podmiotami, można przejść do analizy faktycznego zaangażowania organizacji w budowanie sieci współpracy i kontaktów. Wszystkie badane organizacje (11 instytucji) deklaruje chęć nawiązywania kontaktów (dzielenie się informacjami, wydarzeniami, doświadczeniem) oraz współpracy (partnerstwo przy realizacji działań, angażowanie się we wspólne przedsięwzięcia, wolontariat) ze społecznością lokalną. Co ciekawe, więcej organizacji deklaruje nawiązanie współpracy z innymi podmiotami niż same kontakty z nimi. Wyniki tego wskaźnika są zbieżne z prezentowanymi wcześniej celami działania na portalu społecznościowym. Podobna liczba organizacji stawiała sobie za cel współpracę/kontakty z organizacjami pozarządowymi, jaka faktycznie deklaruje realizację takiej współpracy. 
Wykres 5. Nawiązywanie kontaktów i współpracy dzięki aktywności na portalu społecznościowym

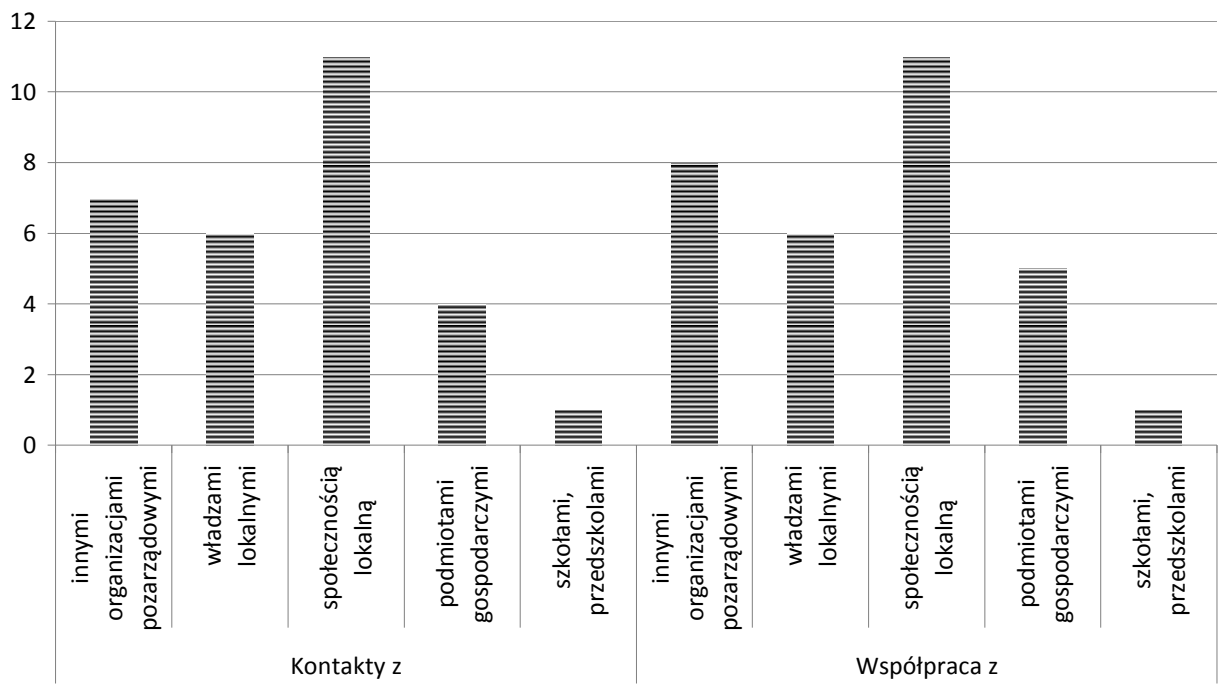

Źródło: Opracowania własne na podstawie danych zgromadzonych podczas badania

W najmniejszym stopniu, przy wykorzystaniu portali społecznościowych, zachodzą interakcje między badanymi jednostkami, a podmiotami gospodarczymi $^{13}$. Sytuacja ta może po pierwsze wynikać $\mathrm{z}$ faktu, że jedynie 2 spośród 11 organizacji wskazały podmioty prywatne, jako partnerów swoich działań. Po drugie natomiast, gdy respondenci zostali zapytani o ich zdaniem najaktywniejsze "grupy” na portalu, to przedsiębiorcy nie otrzymali żadnego wskazania. Grupą, która według badanych najczęściej angażuje się we współpracę poprzez serwis społecznościowy jest bezdyskusyjnie młodzież (uczniowie i studenci). Wszystkie organizacje wskazały ją jednogłośnie. Drugie miejsce, dzięki pozytywnej opinii 4 organizacji, zajęli szeroko rozumiani przedstawiciele władzy.

Z punktu widzenia wymiany informacji i wiedzy, bardzo istotny jest również charakter kontaktów i współpracy, nawiązywanych przez użytkowników portalu społecznościowego. Im jest on stabilniejszy, dłuższy i jego częstotliwość jest większa, tym partnerzy mają większą szansę lepiej poznać się nawzajem, wypracować zaufanie, a tym samym zwiększyć skłonność do dzielenia się zasobami, w tym również informacji i wiedzy. Tabela 1 przedstawia, jaki charakter mają najczęściej kontakty nawiązywane z wyróżnionymi jednostkami.

${ }^{13}$ Szkoły i przedszkola zostały wskazane przez jedną organizację w dodatkowej kategorii: „inne, jakie?”. 
214 Wpływ sieci społecznościowych na wartość kapitału ludzkiego...

Tabela 1. Charakter kontaktów nawiązanych z innymi podmiotami dzięki aktywności na portalu społecznościowym

\begin{tabular}{|l|c|c|c|c|}
\hline & $\begin{array}{c}\text { Krótkotrwały } \\
\text { (do 6 miesięcy) }\end{array}$ & $\begin{array}{c}\text { Długotrwały } \\
\text { (powyżej 6 } \\
\text { miesięcy) }\end{array}$ & $\begin{array}{c}\text { Incydentalny } \\
\text { (tylko raz, przy } \\
\text { konkretnym } \\
\text { projekcie) }\end{array}$ & $\begin{array}{c}\text { Brak nawiaza- } \\
\text { nych kontaktów }\end{array}$ \\
\hline $\begin{array}{l}\text { Kontakty z innymi organi- } \\
\text { zacjami pozarządowymi }\end{array}$ & 2 & 3 & 4 & 2 \\
\hline $\begin{array}{l}\text { Kontakty z władzami } \\
\text { lokalnymi }\end{array}$ & 0 & 4 & 3 & 4 \\
\hline $\begin{array}{l}\text { Kontakty ze społeczno- } \\
\text { ścią lokalną }\end{array}$ & 1 & 8 & 2 & 0 \\
\hline $\begin{array}{l}\text { Kontakty z podmiotami } \\
\text { gospodarczymi }\end{array}$ & 0 & 3 & 2 & 6 \\
\hline
\end{tabular}

Źródło: Opracowania własne na podstawie danych zgromadzonych podczas badania

Największa systematyczność współpracy z organizacjami pozarządowymi widoczna jest w przypadku społeczności lokalnej. 8 spośród badanych jednostek deklaruje, że mieszkańcy ciągle angażują się we współpracę za pomocą serwisu. W tym przypadku znów potwierdza się opinia, że najmniejsza aktywność w kontekście jakichkolwiek kontaktów i współpracy dotyczy interakcji z podmiotami gospodarczymi. W przypadku współpracy z władzami lokalnymi, zdania organizacji zostały dość wyraźnie podzielone. Wśród tych organizacji, które ową współpracę z nimi w ogóle deklarują, oceny rozkładają się praktycznie po połowie i co ciekawe dość skrajnie, gdyż 4 podmioty definiują ją jako długotrwała, natomiast 3 jako incydentalną.

Wykres 6. Lokalizacja podmiotów zaangażowanych i wspierających działalność organizacji poprzez portal społecznościowy

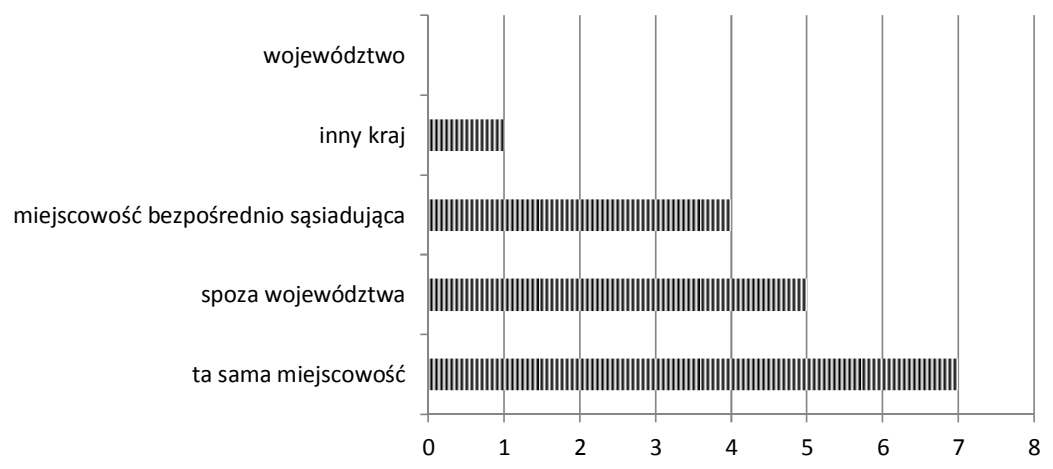

Źródło: Opracowania własne na podstawie danych zgromadzonych podczas badania 
Wnioskowanie na temat zasięgu przestrzennego budowanych sieci współpracy i dyfuzji wiedzy z wykorzystaniem portalu społecznościowego, będzie możliwe dzięki zweryfikowaniu lokalizacji najczęściej kontaktujących się podmiotów. Dodatkowo, może mieć to też konsekwencje w przypadku chęci przeniesienia kontaktów i działania ze świata wirtualnego do realnego.

Uzyskane wyniki, biorąc pod uwagę specyfikę narzędzi informacyjnokomunikacyjnych, są niezwykle ciekawe. Podstawową cechą technologii ICT jest ich aprzestrzenny charakter. Jako siła ich sukcesu wskazywany jest brak przywiązania do danego terytorium i możliwość globalnego włączenia się w działania z każdego miejsca na świecie. Aspekt ten podnoszony jest najczęściej, jako największa korzyść płynąca z dostępu i wykorzystania tych narzędzi. Jednak jak widać w przypadku analizowanych jednostek, tendencja ta nie znalazła potwierdzenia. Wręcz przeciwnie, 7 spośród 11 respondentów deklarowało, że najbardziej zaangażowanymi podmiotami we wsparcie działalności organizacji przy wykorzystaniu portalu społecznościowego są jednostki pochodzące z tej samej miejscowości. Można wnioskować, że mimo dostępu do szerokiego grona odbiorców, dzięki portalowi aktywizuje się głównie społeczność lokalna, tworząc lokalne sieci współpracy. Oczywiście pojawiły się również wskazania na współpracę z jednostkami z miejscowości sąsiednich, czy spoza województwa, jednak pozostaje zdecydowana wątpliwość, czy narzędzia ICT rzeczywiście można postrzegać przede wszystkim jako instrumenty do budowania współpracy i komunikowania się w skali globalnej, czy jednak powinno się zwrócić większą uwagę na ich rolę w kształtowaniu lokalnej aktywności i współpracy podmiotów.

Podsumowaniem fragmentu analizy, skupiającego się na ocenie znaczenia portalu w budowaniu sieci współpracy, jest sprawdzenie, czy wśród badanych organizacji rzeczywiście zostały nawiązane kontakty, bądź jest realizowana współpraca, która nie miałaby szans zaistnieć bez ich aktywności w serwisie społecznościowym. W tym przypadku odpowiedzi były w zasadzie równo podzielone. 4 organizacje stwierdziły, że taka współpraca faktycznie została nawiązana, ale również 4 inne zaprzeczyły i uznały, że aktywność na portalu nie była warunkiem koniecznym do tego, by dane kontakty, czy współpraca zostały zainicjowane. $Z$ kolei 3 pozostałe podmioty nie potrafiły jasno odpowiedzieć na to pytanie. Trudno tym samym jednoznacznie wnioskować o dużej i deterministycznej roli aktywności na portalu społecznościowym, dla budowania sieci kontaktów i współpracy.

Pytanie zatem, w jakim innym obszarze, czy zakresie organizacje pozarządowe definiują korzyści płynące $\mathrm{z}$ włączenia się do społeczności portalu, a w szczególności, czy wykreowane sieci kontaktów i współpracy przyczynia się ich zdaniem do dyfuzji wiedzy. Problem ten otwiera ostatni obszar prowadzonej analizy, która w tym przypadku skupiać się będzie na prezentacji danych, pokazujących wpływ zbudowanych relacji na procesy wymiany informacji i wiedzy. 
$\mathrm{Na}$ tej podstawie możliwa będzie ocena, na ile kapitał społeczny wykreowany dzięki aktywności na portalu społecznościowym (sieci kontaktów i współpracy), decyduje o wartości kapitału ludzkiego poprzez wpływ na procesy zdobywania jego podstawowego czynnika - wiedzy. Czy zatem budowanie sieci współpracy i kontaktów na portalach społecznościowych można traktować, jako swojego rodzaju inwestycję $\mathrm{w}$ wartość kapitału ludzkiego. W tym miejscu warto przede wszystkim przyjrzeć się wskazywanym przez respondentów korzyściom, efektom, rezultatom ich funkcjonowania na portalu społecznościowym. Co w ich subiektywnej ocenie stanowi wartość dodaną dla organizacji wynikającą z aktywności na serwisie? Wnioskiem zdecydowanie pozytywnym jest to, że wszystkie spośród badanych organizacji potrafią zidentyfikować pozytywne rezultaty determinowane przynależnością do społeczności portalu. Analiza wyników pokazuje, że dla respondentów najistotniejszą korzyścią znów jest nawiązanie interakcji ze społecznością. Właśnie ten element jest najważniejszym i najczęściej wskazywanym rezultatem podejmowanej aktywności (wykres 7).

Wykres 7. Identyfikowane efekty i korzyści wynikające z funkcjonowania organizacji na portalu społecznościowym

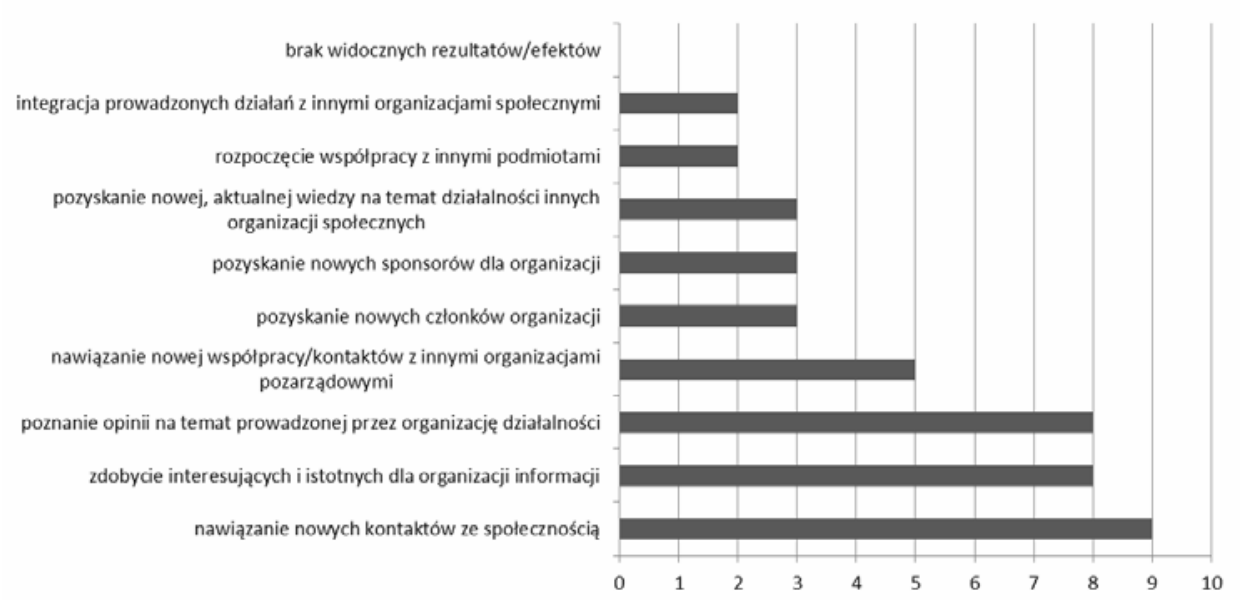

Źródło: Opracowania własne na podstawie danych zgromadzonych podczas badania

$\mathrm{Na}$ drugim miejscu znajduje się zdobywanie informacji, interesujących $i$ istotnych dla organizacji oraz poznawanie opinii na temat prowadzonej przez nią działalności (istotność tego efektu deklaruje 8 spośród 11 badanych organizacji). Respondenci w swojej ocenie zwracają uwagę na mniej widoczne $i$ istotne rezultaty, w szczególności związane w prowadzonych działaniach $\mathrm{z}$ integracją z innymi organizacjami społecznymi oraz rozpoczęciem współpracy z inny- 
mi podmiotami. Faktycznie jest to zbieżne z wcześniejszą analizą wskaźników, obrazujących poziom współpracy i kontaktów z innymi jednostkami - wówczas najwięcej spośród badanych organizacji wskazywało na istotność relacji ze społecznością. Uzupełniając wątek korzyści i efektów wykorzystania portalu społecznościowego, respondenci zostali zapytani, czy aktywność i zaangażowanie danych jednostek na portalu przenosi się z czasem do świata rzeczywistego? Czy jednostki te angażują się w realną działalność organizacji? Nie zostały, co prawda, zidentyfikowane specyficzne warunki, jakie determinują to przeniesienie i z pewnością muszą zaistnieć, by ono nastapiło, ale 9 z 11 organizacji potwierdziło, że faktycznie takie przeniesienie aktywności następuje. Jedna organizacja zaprzeczyła tej tezie i jedna zwróciła uwagę, że występuje zależność odwrotna przeniesienie rzeczywistej, realnej aktywności i współpracy do świata wirtualnego, w której portal sprowadza się do narzędzia podtrzymującego już realizowaną kooperację i nawiązane kontakty. Co ciekawe $60 \%$ spośród respondentów, którzy potwierdzili przeniesienie nawiązanych kontaktów w sieci do świata realnego stwierdziło, że to realne, rzeczywiste zaangażowanie jest $\mathrm{z}$ reguły zaangażowaniem cyklicznym (jednostki co pewien czas angażują się w wybrane projekty).

Wykres 8. Rodzaj zaangażowania w realną działalność organizacji wynikający ze współpracy na portalu społecznościowym

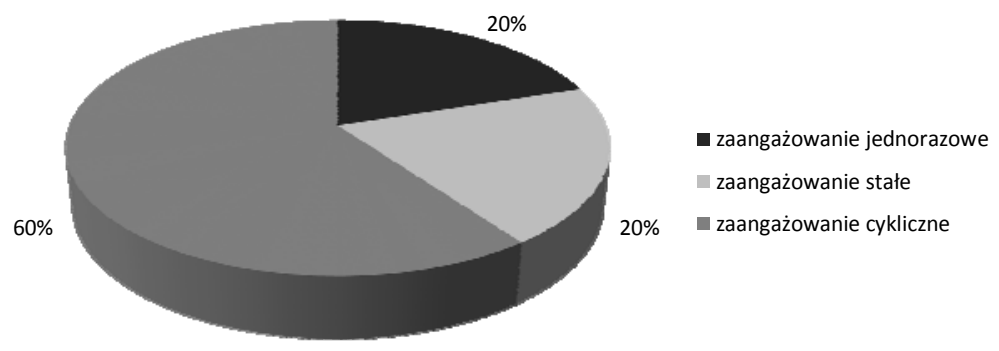

Źródło: Opracowania własne na podstawie danych zgromadzonych podczas badania.

Pozostałe opinie podzieliły się po równo i dla $20 \%$ badanych przeniesione relacje mają charakter zaangażowania jednorazowego (tylko przy jednym konkretnym projekcie, przedsięwzięciu). Z kolei dla pozostałych $20 \%$ respondentów realne zaangażowanie jest stałe - w wyniku zapoczątkowania współpracy i nawiązania kontaktów w sieci jednostki wiążą się na stałe z organizacją (w sposób ciaggły i systematyczny uczestniczą w jej działalności i ją wspierają). 
Pozostaje ostatnia kwestia oceny, czy i w jakim stopniu, zaangażowaniu badanych organizacji, w budowanie sieci relacji i współpracy na portalu społecznościowym, towarzyszy transfer wiedzy? Jak zostało wskazane powyżej, jednym z najczęściej wskazywanych efektów i korzyści wykorzystania portalu, było zdobycie informacji interesujących i istotnych dla danej organizacji. Najwięcej spośród zapytanych o to respondentów stwierdziło, że są to najczęściej informacje, na temat podstawowych faktów dotyczących działalności innych podmiotów będących członkami serwisu. (Choć przypomnieć należy, że ani możliwość bieżącej obserwacji i kontroli działań innych organizacji pozarządowych, ani pozyskiwanie aktualnych informacji o działalności innych organizacji pozarządowych, nie było najczęściej wskazywane jako główny cel aktywności na portalu). Drugi, co do popularności rodzaj zdobytej wiedzy dotyczył poznania pewnych reguł panujących $\mathrm{w}$ społeczeństwie, związanych $\mathrm{np}$. $\mathrm{z}$ chęciami, preferencjami, postawami społeczeństwa wobec zaangażowania się w życie i sprawy publiczne. Dwa kolejne rodzaje wiedzy, transferowane dzięki portalowi, były wskazane przez 5 spośród wszystkich badanych organizacji. Dotyczyły one możliwości dostępu i dzielenia się wiedzą ekspercką, płynącą z doświadczeń innych podmiotów np. na temat zrealizowania dużego projektu, zorganizowania konkretnego przedsięwzięcia oraz wiedzą na temat tego, kto może posiadać daną istotną informację (wykres 9).

Wykres 9. Rodzaje wiedzy transferowane dzięki aktywności na portalu społecznościowym

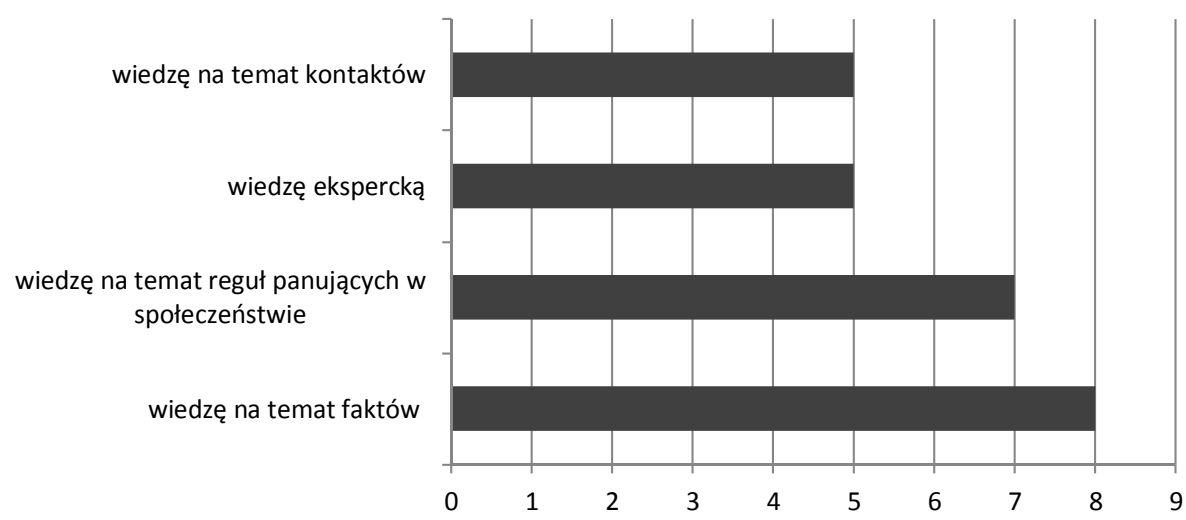

Źródło: Opracowania własne na podstawie danych zgromadzonych podczas badania.

Korzystając zatem z klasycznego funkcjonalnego podziału wiedzy widać wyraźnie, że najwięcej organizacji koncentruje swoją uwagę na tym, co dzieje się w środowisku, w którym się znajduje, w jej otoczeniu i jest tym samym 
związane z jej bieżącym funkcjonowaniem. W dalszej kolejności wykorzystują swą aktywność na portalach, by wiedzieć jakie reguły i dlaczego rządzą w danym społeczeństwie. Kolejne dwa rodzaje wiedzy, czyli „wiedzieć jak” i „wiedzieć kto", są wskazywane jako najrzadziej transferowane dzięki portalowi. Należy jednak zauważyć, że transfer wiedzy eksperckiej z reguły jest bardzo trudny, a publiczny dostęp do niej w znacznej mierze ograniczony. Jednak respondenci, rozwijając swe odpowiedzi w tym zakresie, zwracali bardziej uwage na możliwość wymiany doświadczeń i dobrych praktyk, które zostały wcześniej wykorzystane i sprawdzone przez innych członków portalu. Niepokojące jest jednak stosunkowo niewielkie wykorzystanie portalu do zdobywania i dzielenia się informacjami na temat tego, kto posiada określoną wiedzę. Może to świadczyć o mniejszej chęci ujawniania źródeł kontaktów, co wyklucza się z ideą budowania i funkcjonowania sieci współpracy społecznej, bądź niedojrzałością środowiska wirtualnego (brakiem zaufania, kapitału społecznego). Rozszerzając ten wątek analizy, respondenci wskazali dodatkowo, do jakich innych celów i jakie inne działania zostają usprawnione dzięki informacjom i wiedzy zdobytej na portalu. Wszystkie organizacje jednogłośnie wskazały na pomoc w skuteczniejszym określaniu popularności różnych rodzajów działań. Na drugim miejscu, wskazana przez 8 podmiotów, znalazła się możliwość trafniejszej oceny potencjalnego powodzenia podejmowanych przedsięwzięć oraz możliwość sprawnego odszukania miejsc, gdzie można znaleźć nowe idee, pomysły na inicjatywę (tabela 2).

Tabela 2. Możliwości wykorzystania wiedzy i informacji zdobytych na portalu społecznościowym

\begin{tabular}{|l|c|c|c|}
\hline & \multicolumn{3}{|c|}{ Liczba odpowiedzi } \\
\cline { 2 - 4 } & Tak & Nie & Trudno powiedzieć \\
\hline $\begin{array}{l}\text { określenie które działania podejmowane } \\
\text { przez organizacje ciesza się wśród } \\
\text { społeczności większym zainteresowaniem, } \\
\text { popularnością }\end{array}$ & 11 & 0 & 0 \\
\hline $\begin{array}{l}\text { ustalenie kiedy powinny być realizowane } \\
\text { dane przedsięwzięcia, które działania } \\
\text { powinny być podejmowane w pierwszej } \\
\text { kolejności }\end{array}$ & 2 & 4 & 5 \\
\hline $\begin{array}{l}\text { zrozumienie relacji panujacych między } \\
\text { organizacjami, organizacjami a } \\
\text { społecznościa, organizacjami a władza } \\
\text { lokalna }\end{array}$ & 2 & 4 & 5 \\
\hline $\begin{array}{l}\text { znajomość miejsc, gdzie można szukać } \\
\text { nowych idei, parterów współpracy, } \\
\text { pomysłów na nowe inicjatywy }\end{array}$ & 7 & & \\
\hline $\begin{array}{l}\text { Ocena możliwości powodzenia } \\
\text { podejmowanych działań }\end{array}$ & 8 & 2 & 2 \\
\hline \hline
\end{tabular}

Źródło: Opracowania własne na podstawie danych zgromadzonych podczas badania 
Wśród respondentów negatywna ocena odnosiła się do dwóch możliwości. Pierwsza z nich dotyczyła lepszego zrozumienia relacji panujących między organizacjami, kolejna zaś trafniejszego ustalenia harmonogramu podejmowanych działań. W obu przypadkach organizacje nie były pewne, czy aktywność na portalu i związany z nią dostęp do wiedzy i informacji w znaczący sposób ulepszą te procesy. Co ciekawe, organizacje, które jako najistotniejsze efekty wynikające z aktywności na portalu społecznościowym wskazywały nawiązywanie kontaktów ze społecznością lokalną, innymi organizacjami pozarządowymi i pozostałymi podmiotami, deklarowały jednocześnie większe korzyści dla własnej działalności, związane $\mathrm{z}$ wykorzystaniem różnorodnych rodzajów wiedzy. Biorąc pod uwagę liczbę grup podmiotów, $\mathrm{z}$ którymi współpracowały organizacje, to wraz z ich wzrostem nie jest widoczna szersza wymiana wiedzy. Jednak ankietowani nie byli pytani o liczebność każdej grupy, z którą deklarowały współpracę, dlatego należy ostrożnie interpretować tę zależność. Tym bardziej, że transfer różnorodnej wiedzy jest silniej widoczny w przypadku organizacji, które deklarowały posiadanie bardziej rozbudowanego profilu swojej działalności (mierzonego liczbą znajomych, „fanów” profilu). Widoczna jest też zależność pomiędzy poziomem korzystania $\mathrm{z}$ innych narzędzi komunikacyjnych (oprócz portalu społecznościowego), a deklaracją korzystania z różnych rodzajów wiedzy. Wśród organizacji, które wykorzystywały więcej takich narzędzi, deklarowany dostęp i wykorzystanie wiedzy są większe. Fakty te dają podstawy do potwierdzenia, że bardziej rozbudowana sieć kontaktów oraz większa aktywność w zakresie wykorzystania narzędzi informacyjno-komunikacyjnych powoduje łatwiejszą i szerszą wymianę wiedzy.

\section{Wnioski i rekomendacje}

Kwestie związane z rozwojem kapitału ludzkiego, a przede wszystkim nieustannym inwestowaniem w jego wartość, są zagadnieniem kluczowym w obliczu przemian gospodarczych XXI wieku. Przejście od gospodarki materiałochłonnej do wiedzochłonnej, od dominacji przemysłu w wytwarzaniu dochodu narodowego, do dominacji usług wyższego rzędu spowodowało, że najistotniejszy dla szeroko rozumianego rozwoju stał się wykształcony, kreatywny i wysoko wykwalifikowany kapitał ludzki. Jednak dodatkowo, tendencje związane z rozwojem i upowszechnianiem technologii informacyjno-komunikacyjnych oraz zmiana logiki funkcjonowania społeczeństwa i gospodarki w kierunku działania w sieciach, powodują, że warto spojrzeć na inwestycje w kapitał społeczny jako akceleratora i dyfuzora inwestycji w człowieka i pomnażanie zasobów wiedzy. Owe tendencje stwarzają bowiem nie tylko nowe warunki, w których inwestycje te się dokonują, ale przede wszystkim nowe możliwości wzrostu ich efek- 
tywności. W pracy podjęto próbę wykazania, że budowanie sieci współpracy przy wykorzystaniu technologii ICT może wpływać na wartość kapitału ludzkiego, głównie poprzez modyfikację procesów komunikacji i współpracy.

Badania koncentrowały się na analizie zachowań wybranych organizacji pozarządowych regionu łódzkiego, związanych z praktycznym wykorzystaniem narzędzi informacyjno-komunikacyjnych, w procesie dyfuzji wiedzy. Szczegółowa analiza zgromadzonego materiału badawczego pozwoliła na sformułowanie pewnych ogólnych wniosków, w odniesieniu do postawionych pytań badawczych i realizowanego celu pracy.

Sama skłonność do wykorzystania najbardziej interaktywnych narzędzi informacyjno-komunikacyjnych, które w największym stopniu umożliwiają kontakty między podmiotami i tym samym dają szansę wytworzenia przyjaznego środowiska współpracy i wymiany wiedzy, jest jeszcze stosunkowo niewielka. Potwierdzeniem tego wniosku jest mała liczba organizacji z wybranych do badania miast, która w ogóle posiadała konto na najbardziej popularnym portalu społecznościowym, a także niewielkie zainteresowanie wśród ankietowanych, innymi narzędziami służącymi do komunikacji, dzielenia się informacjami, pomysłami, wiedzą, doświadczeniami. Może to świadczyć z jednej strony o braku świadomości, co do potencjalnych korzyści, jakie daje ich wykorzystanie dla funkcjonowania podmiotów, strachu przed brakiem umiejętności poruszania się w nowym, nieznanym jeszcze środowisku, lub o tym, że narzędzia te (szczególnie portale społecznościowe), zaczęły rozwijać się i zadomawiać w Polsce dopiero od kilku lat i nie są jeszcze wszystkim dobrze znane. Tym bardziej potwierdza to zasadność podejmowanego tematu. $Z$ badań wynika, że najbardziej prawdopodobna jest sytuacja pierwsza, gdyż organizacje, które już korzystają z portalu społecznościowego i poznały jego możliwości, odwiedzają go w większości przypadków przynajmniej raz dziennie. Częstsze korzystanie z portalu cechuje również podmioty, które mają większą liczbę znajomych, „fanów” swojej działalności. Większa sieć kontaktów, motywuje je jednocześnie do większej aktywności, w oczekiwaniu na większe korzyści dla własnej działalności. Widoczne są zatem pewne pozytywne tendencje rozwijającej się aktywności podmiotów na portalu.

Ciekawy wniosek wynika również z faktu, że organizacjom wcale nie zależy najbardziej na podtrzymaniu już posiadanych kontaktów dzięki dołączeniu do portalu. Wśród motywów decydujących o wykorzystaniu portalu przeważały te najczęściej wskazywane przy innych analizach, dotyczących narzędzi informacyjno-komunikacyjnych - łatwość dostępu z każdego miejsca i w każdym czasie oraz ich popularność. Ogólna świadomość korzyści i możliwości wykorzystania portali jako narzędzi do komunikacji, czy budowania sieci współpracy, niestety wciąż nie jest na wysokim poziomie. Pojawia się ona wśród użytkowników dopiero po pewnym czasie funkcjonowania na portalu. Zauważają wówczas, że 
portal społecznościowy z powodzeniem może być traktowany jako narzędzie nie tylko do autoprezentacji i promocji własnej działalności, ale również jako platforma wymiany doświadczeń, wiedzy, pomysłów i budowania współpracy. $\mathrm{W}$ konsekwencji istotne jest ciagłe uświadamianie potencjału, tkwiącego $\mathrm{w}$ tego rodzaju narzędziach, w zakresie budowania kooperacji i partnerstw.

Intensywność kontaktów uzależniona jest od grupy, rodzaju podmiotów, które angażują się we współpracę. W przypadku niektórych podmiotów istnieje tylko chęć uzyskania jednorazowego wsparcia czy korzyści, bez skłonności do nawiązania długotrwałej współpracy. Grupa, która w największym stopniu wyraża gotowość na systematyczną współpracę jest społeczność lokalna. Taka postawa, z punktu widzenia inwestycji w kapitał ludzki i budowania jego wartości, przynosi najlepsze efekty. Oprócz tego, że pozwala ona na ciagły dostęp do wiedzy i informacji, to dodatkowo daje szanse na zbudowanie odpowiedniego poziomu zaufania, niezbędnego do usprawnienia procesów kooperacji, współdziałania.

$\mathrm{Na}$ uwagę zasługuje również fakt, że w wyniku wykorzystania narzędzi informacyjno-komunikacyjnych, typu portale społecznościowe, następuje transfer wiedzy przede wszystkim w ujęciu lokalnym. We współpracę poprzez portal najczęściej angażuje się społeczność i podmioty z tego samego miasta. Budowane sieci współpracy mają zatem zazwyczaj charakter lokalny, i co ważne, w zdecydowanej większości przenoszą się i są kontynuowane w świecie realnym. Przeniesienie zaangażowania do rzeczywistości ma zazwyczaj charakter cykliczny, jednak i tak może generować korzyści dla rozwoju społecznogospodarczego danego terytorium. Powstałe społeczności wirtualne nie są więc całkowicie oderwane od terytorium, w którym funkcjonują ich członkowie. Ich współpraca w sieci i wymiana doświadczeń może mieć korzystne efekty w wymiarze terytorialnym. Uzasadniona może być tym samym próba inwestowania i świadomego kształtowania tego rodzaju społeczności w celu uzyskania konkretnych korzyści dla danego terytorium i podnoszenia wartości jego zasobów. Mogą one okazać się nowym, wartościowym potencjałem, który odpowiednio wykorzystany będzie wpływał na sposób organizacji i funkcjonowania rzeczywistości społeczno-gospodarczej danego obszaru i w pewnym stopniu modyfikował jego zasoby.

Mimo coraz większej popularności serwisów społecznościowych, nie mają one jeszcze deterministycznego znaczenia w zakresie kreowania współpracy. Aktywność w sieci nie jest traktowana jako element konieczny w procesie nawiązywania kontaktów. Bez względu na to, nie ma wątpliwości, że narzędzia te umożliwiają, ułatwiają i aktywizują podmioty do wymiany wiedzy, wpływając tym samym na wartość kapitału ludzkiego. Jednak w kontekście samej wymiany wiedzy, zaobserwowana praktyka odbiega nieco od teorii. O ile nie dziwi ograniczona skłonność do wymiany wiedzy eksperckiej, specjalistycznej, to cieka- 
wym faktem jest niewielki stopień dzielenia się wiedzą o kontaktach, który jest sprzeczny z samą ideą działania w sieci i aktywności na portalu społecznościowym.

Reasumując, na podstawie przeprowadzonych badań, można stwierdzić, że portale społecznościowe zaczynają być traktowane i świadomie wykorzystywane, jako narzędzia użyteczne do dzielenia się i wymiany wiedzy, w konsekwencji zwiększania wartości kapitału ludzkiego. Zagadnienia związane z identyfikacją roli narzędzi informacyjno-komunikacyjnych w kształtowaniu kapitału społecznego, jako czynnika decydującego o efektywności wykorzystania zasobów ludzkich, są obszarem bardzo szerokim, złożonym i dynamicznie rozwijającym się. Precyzyjne rozpoznanie zachodzących w nim zależności wymaga kompleksowego spojrzenia na problem, zarówno przez pryzmat organizacji procesów komunikacji, dyfuzji wiedzy, czy budowania relacji. W obliczu współczesnych wyzwań i uwarunkowań rozwoju, konieczne okazuje się przesunięcie akcentu na działania partnerskie, oparte na szerokiej współpracy i relacjach sieciowych. Wyzwaniem, w kontekście inwestowania w rozwój kapitału ludzkiego, może okazać się zatem tworzenie nowej przestrzeni, przyjaznej dla współdziałania i budowania postaw zaufania - przestrzeni integrującej i sprzyjającej nawiązywaniu kontaktów.

\section{Bibliografia}

Czapiński J., Panek T. (red.), Diagnoza społeczna 2007. Warunki i jakość życia Polaków. Raport, Warszawa 2007.

Europe Digital Future in Focus 2013, comScore, http://www.comscore.com/Insights/Blog/ 2013 Digital_Future in Focus_Series.

Jewtuchowicz A., Rozwój, środowisko, sieci innowacyjne i lokalne systemy produkcyjne, [w:] Zewnętrzne determinanty rozwoju innowacyjnych firm, K. B. Matusiak, E. Stawasz,

A. Jewtuchowicz, Katedra Ekonomii Uniwersytetu Łódzkiego, Łódź 2001.

Kietlińska K., Rola trzeciego sektora w spoleczeństwie obywatelskim, Wydawnictwo Difin, Warszawa 2010.

Moroń D., Aktywność w trzecim sektorze jako jeden z wymiarów kapitatu społecznego [w:] Kapitat ludzki i spoleczny. Wybrane problemy teorii i praktyki, D. Moroń (red.), Wydawnictwo Uniwersytetu Wrocławskiego, Wrocław 2009.

Putnam R.D., Demokracja w działaniu: tradycje obywatelskie we wspótczesnych Wtoszech, Instytut Wydawniczy Znak, Fundacja im. Stefana Batorego, KrakówWarszawa 1995.

Shih C., Era Facebooka. Wykorzystaj sieci spolecznościowe do promocji, sprzedaży i komunikacji z Twoim kliente. Wydanie II, Wydawnictwo HELION, Gliwice 2012.

Skrzyńska J., Badanie: Zaangażowanie Społeczne Polaków, Zespół Badań Społecznych OBOP w TNS Polska.

Ustawa z dnia 24 kwietnia 2003 r. o działalności pożytku publicznego i o wolontariacie, Dz. U. 2003 Nr 96, poz. 873, Art. 3. 